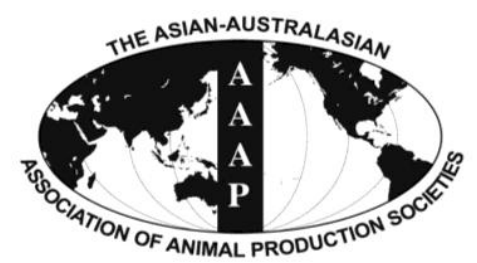

Asian Australas. J. Anim. Sci.

Vol. 26, No. 7 : 952-960 July 2013

http://dx.doi.org/10.5713/ajas.2013.13032

www.ajas.info

pISSN 1011-2367 elSSN 1976-5517

\title{
Effect of Carbohydrate Source and Cottonseed Meal Level in the Concentrate on Feed Intake, Nutrient Digestibility, Rumen Fermentation and Microbial Protein Synthesis in Swamp Buffaloes
}

\author{
M. Wanapat*, R. Pilajun ${ }^{1}$, S. Polyorach, A. Cherdthong, P. Khejornsart ${ }^{2}$, and P. Rowlinson ${ }^{3}$ \\ Tropical Feed Resources Research and Development Center (TROFREC), Department of Animal Science, \\ Faculty of Agriculture, Khon Kaen University, Khon Kaen 40002, Thailand
}

\begin{abstract}
The objective of this study was to investigate the effect of carbohydrate source and cottonseed meal level in the concentrate on feed intake, nutrient digestibility, rumen fermentation and microbial protein synthesis in swamp buffaloes. Four, 4-yr old rumen fistulated swamp buffaloes were randomly assigned to receive four dietary treatments according to a $2 \times 2$ factorial arrangement in a 4×4 Latin square design. Factor A was carbohydrate source; cassava chip (CC) and CC+rice bran at a ratio 3:1 (CR3:1), and factor B was level of cottonseed meal (CM); $109 \mathrm{~g} \mathrm{CP} / \mathrm{kg}$ (LCM) and $328 \mathrm{~g} \mathrm{CP} / \mathrm{kg}$ (HCM) in isonitrogenous diets (490 g CP/kg). Buffaloes received urea-treated rice straw ad libitum and supplemented with $5 \mathrm{~g}$ concentrate/kg BW. It was found that carbohydrate source did not affect feed intake, nutrient intake, digested nutrients, nutrient digestibility, ammonia nitrogen concentration, fungi and bacterial populations, or microbial protein synthesis ( $\mathrm{p}>0.05$ ). Ruminal $\mathrm{pH}$ at $6 \mathrm{~h}$ after feeding and the population of protozoa at $4 \mathrm{~h}$ after feeding were higher when buffalo were fed with CC than in the CR3:1 treatment $(\mathrm{p}<0.05)$. Buffalo fed with HCM had a lower roughage intake, nutrient intake, population of total viable and cellulolytic bacteria and microbial nitrogen supply than the LCM fed group ( $\mathrm{p}<0.05$ ). However, nutrient digestibility, ruminal $\mathrm{pH}$, ammonia concentration, population of protozoa and fungi, and efficiency of microbial protein synthesis were not affected by cottonseed meal levels ( $>0.05$ ). Based on this experiment, concentrate with a low level of cottonseed meal could be fed with cassava chips as an energy source in swamp buffalo receiving rice straw. (Key Words: Carbohydrate Source, Cottonseed Meal, Rumen Fermentation, Microbial Population, Swamp Buffalo)
\end{abstract}

\section{INTRODUCTION}

The considerable increase in feed costs when animal diets are based on imported feedstuffs has necessitated a search for cheaper energy and protein sources on farm to replace expensive feed resources. Cassava (Manihot esculenta) tubers contain high levels of energy (Wanapat,

\footnotetext{
* Corresponding Author: Metha Wanapat. Tel: +66-043-202368, Fax: +66-043-202368, E-mail: metha@kku.ac.th

${ }^{1}$ Department of Animal Science, Faculty of Agriculture, Ubon Ratchathani University, Ubon Ratchathani 34190, Thailand.

${ }^{2}$ Agro-Bioresources, Faculty of Natural Resources and AgroIndustry, Kasetsart University Chalermphakiat Sakon Nakhon province campus, Thailand.

${ }^{3}$ School of Agriculture, Food and Rural Development Agriculture Building, Newcastle University, Newcastle upon Tyne, NE1 7RU, United Kingdom.

Submitted Jan. 10, 2013; Accepted Mar. 11, 2013; Revised Mar. 14, 2013
}

2003) and have been used as a source of readily fermentable energy in beef cattle (Wanapat and Khampa, 2007), dairy cattle (Khampa et al., 2006) and buffalo (Etman et al., 1993; Wanapat et al., 2009) rations. Moreover, by-products from oilseed factories are amongst the potential protein sources available widely (Wanapat, 2009). This is especially true of cottonseed meal which contains a high proportion of rumen undegradable protein (Grings et al., 1991). These could be beneficial for improvement of animal performance by incorporating with low degraded carbohydrate. Rice bran was combined with cassava chip, as it is slowly degraded carbohydrate in the rumen which could be incorporated with cottonseed meal for improvement of animal production Our previous studies revealed that using combination of cassava chip and rice bran as carbohydrate sources can improve digestibility, populations of total viable bacteria and proteolytic bacteria (Wanapat et al., 2013). While, using high level of cotton seed meal in the diet, it can further 
improve total feed intake, milk yield, milk composition and milk income in dairy cows (Wanapat et al., 2012). Moreover, nitrogen balance and volatile fatty acids were remarkably increased when young dairy bulls fed on the concentrate with cottonseed meal (Wanapat et al., 2013). However, the study of carbohydrate source and cottonseed meal level has not been done with swamp buffaloes. Therefore, this study was conducted to investigate the effects of carbohydrate source and level of cottonseed meal in the concentrate on dry matter intake, nutrient digestibility, rumen fermentation, microbial population and microbial protein synthesis in swamp buffaloes fed on a diet based on urea-treated rice straw.

\section{MATERIALS AND METHODS}

\section{Animals and feeds}

Four, 4-yr old rumen fistulated swamp buffalo bulls with a body weight of $400 \pm 15 \mathrm{~kg}$ were randomly assigned to receive dietary treatments according to a $2 \times 2$ factorial arrangement in a $4 \times 4$ Latin square design with 4 dietary treatments. Factor A was carbohydrate source; cassava chip (CC): $\mathrm{CC}+$ rice bran in a ratio of $3: 1(\mathrm{CR} 3: 1)$, and Factor B was level of cottonseed meal (CM): $109 \mathrm{~g} \mathrm{CP} / \mathrm{kg}$ (LCM) and $328 \mathrm{~g} \mathrm{CP} / \mathrm{kg}$ (HCM) in isonitrogenous diets (490 g $\mathrm{CP} / \mathrm{kg}$ ). The ingredients and chemical composition of the carbohydrate sources and protein concentrates are presented in Table 1. Using rice bran to mix with the cassava chip increased crude protein content from 24 to $49 \mathrm{~g} / \mathrm{kg}$ dry matter while fiber content was slightly increased. The two sources of carbohydrate and two levels of cottonseed meal were mixed at four different ratios to be isonitrogenous of $130 \mathrm{~g} \mathrm{CP} / \mathrm{kg}$ (Table 2).

All buffaloes were supplemented with their respective treatment concentrate at $5 \mathrm{~g} / \mathrm{kg} \mathrm{BW}$ divided into two equal feeds (07.00 and 16.00) and urea-treated rice straw was
Table 1. Ingredients and chemical compositions of diet in the experiment (g/kg DM)

\begin{tabular}{|c|c|c|c|c|}
\hline & \multicolumn{2}{|c|}{ Energy source } & \multicolumn{2}{|c|}{ Protein source } \\
\hline & $\mathrm{CC}$ & CR3:1 & LCM & $\mathrm{HCM}$ \\
\hline \multicolumn{5}{|l|}{ Ingredient } \\
\hline Palm kernel meal & & & 461 & 347 \\
\hline Coconut meal & & & 385 & 297 \\
\hline Cottonseed meal & & & 109 & 328 \\
\hline Urea & & & 109 & 100 \\
\hline Tallow & & & 10 & 10 \\
\hline Molasses & & & 13 & 13 \\
\hline Salt & & & 5 & 5 \\
\hline Sulfur & & & 5 & 5 \\
\hline Mineral & & & 5 & 5 \\
\hline \multicolumn{5}{|l|}{ Chemical composition } \\
\hline Organic matter & 952 & 949 & 926 & 927 \\
\hline Crude protein & 24 & 49 & 491 & 490 \\
\hline Ether extract & 41 & 66 & 98 & 111 \\
\hline Neutral detergent fiber & 140 & 156 & 207 & 266 \\
\hline Acid detergent fiber & 123 & 137 & 154 & 187 \\
\hline
\end{tabular}

given ad libitum. Mineral blocks and water were available ad libitum for all animals which were housed in individual pens.

\section{Samples and analysis}

Measurements of feed intake and collections of feed samples, refusals, feces, rumen fluid, and blood were made during the $21 \mathrm{~d}$ of each period. Rumen fluid and blood samples were collected at $0,2,4$ and 6 h-post feeding while urine and feces were collected via total collection from each individual buffalo during the last $7 \mathrm{~d}$ of each period. The samples were stored at $-20^{\circ} \mathrm{C}$ before analysis, while the daily feces collected in each period were bulked, mixed and

Table 2. Treatment combinations and chemical composition of concentrate and urea treated rice straw $(\mathrm{g} / \mathrm{kg} \mathrm{DM})$

\begin{tabular}{|c|c|c|c|c|c|}
\hline & $\mathrm{T} 1$ & $\mathrm{~T} 2$ & $\mathrm{~T} 3$ & $\mathrm{~T} 4$ & \multirow{2}{*}{ UTRS } \\
\hline & $\mathrm{CC}+\mathrm{LCM}$ & $\mathrm{CC}+\mathrm{HCM}$ & CR3:1+LCM & CR3:1+HCM & \\
\hline \multicolumn{6}{|l|}{ Ingredient $^{1}$} \\
\hline $\mathrm{CC}$ & 773 & 773 & & & \\
\hline CR3:1 & & & 817 & 817 & \\
\hline LCM & 227 & & 183 & & \\
\hline HCM & & 227 & & 183 & \\
\hline \multicolumn{6}{|l|}{ Chemical composition } \\
\hline Organic matter & 949 & 947 & 943 & 945 & 87.1 \\
\hline Crude protein & 130 & 132 & 131 & 132 & 7.5 \\
\hline Ether extract & 54 & 57 & 72 & 74 & - \\
\hline Neutral detergent fiber & 155 & 169 & 165 & 176 & 71.7 \\
\hline Acid detergent fiber & 130 & 138 & 140 & 146 & 52.7 \\
\hline
\end{tabular}

${ }^{1} \mathrm{CC}=$ Cassava chip, CR3:1 = Cassava chip+rice bran 3:1, LCM = Low cottonseed meal, HCM = High cottonseed meal, UTRS = 5\% urea treated rice straw. 
a $50 \mathrm{~g} / \mathrm{kg}$ sub-sample taken for later chemical analysis.

Feeds, feed refusals and fecal samples were dried at $60^{\circ} \mathrm{C}$ and ground $(1 \mathrm{~mm}$ screen using Cyclotech Mill, Tecator, Sweden) and analyzed using the standard methods of AOAC (1995) for dry matter (DM, ID 967.03), ash (ID 942.05) and acid- detergent fiber (ADF, ID 973.18). Neutral- detergent fiber (NDF) was estimated according to Van Soest et al. (1991) with the addition of $\alpha$-amylase but without sodium sulphite and the results were calculated with residual ash. Total nitrogen $(\mathrm{N})$ in samples of feeds, feed refusals, and feces were determined according to AOAC (1991) (ID 984.13). Rumen fluid was immediately measured for $\mathrm{pH}$ using a portable $\mathrm{pH}$ temperature meter (HANNA, instruments HI 8424 microcomputer, Singapore) and $\mathrm{NH}_{3}-\mathrm{N}$ by Kjeltech Auto 1030 Analyzer (Bremmer and Keeney, 1965). Volatile fatty acids were analyzed using High Pressure Liquid Chromatography (Instruments by controller Water model 600E; Water model 484 UV detector; column Novapak C18; column size $3.9 \mathrm{~mm} \times 300$ $\mathrm{mm}$; mobile phase $10 \mathrm{mM} \mathrm{H}_{2} \mathrm{PO}_{4}$ (pH 2.5)) according to Samuel et al. (1997). Rumen fluid was collected for direct count of protozoa and fungal zoospores using the methods of Galyean (1989) by a haemacytometer (Boeco, Singapore) and bacterial groups (total viable, cellulolytic, proteolytic and amylolytic) were measured using the roll-tube technique of Hungate (1969).

Total urine excretion was collected and acidified using $10 \mathrm{ml}$ of $\mathrm{H}_{2} \mathrm{SO}_{4}$ solution $(2 \mathrm{M})$. Urine samples were analyzed for allantoin concentration by high-performance liquid chromatrography, as described by Chen et al. (1993). The supply of microbial $\mathrm{N}(\mathrm{MN})$ was estimated by urinary excretion of purine derivatives (PD) according to Chen and Gomes (1995):

$$
\begin{aligned}
& \mathrm{Y}=0.85 \mathrm{X}+\left(0.385 \mathrm{BW}^{0.75}\right) \\
& \mathrm{MN}(\mathrm{g} / \mathrm{d})=70 \mathrm{X} /(0.116 \times 0.83 \times 1,000)=0.727 \mathrm{X}
\end{aligned}
$$

where $\mathrm{X}$ and $\mathrm{Y}$ are, respectively, absorption and excretion of PD in mmol/d. Efficiency of microbial $\mathrm{N}$ supply (EMNS) was calculated using the following formula:

$$
\text { EMNS }=\text { microbial } \mathrm{N}(\mathrm{g} / \mathrm{d}) / \mathrm{DOMR}
$$

where DOMR = digestible OM apparently fermented in the rumen

\section{Statistical analysis}

All data were statistically analyzed according to a $2 \times 2$ factorial arrangement in a $4 \times 4$ Latin square design using the general linear procedure in GLM procedure of SAS (1996). The statistical model included terms for animal, period, energy source, cottonseed meal level, and interaction between energy source and cottonseed meal level. Unless otherwise stated the significance is reported at $\mathrm{p}<0.05$.

\section{RESULTS}

The effects of carbohydrate source and level of cottonseed meal on voluntary feed and nutrient intake are shown in Table 3. It was found that carbohydrate source did not affect total intake, urea-treated rice straw intake or nutrient intakes ( $p>0.05)$. However, buffalo fed with HCM had a lower total feed intake $(\mathrm{g} / \mathrm{kg} \mathrm{BW})$, urea-treated rice straw intake and nutrient intake including organic matter, neutral detergent fiber and acid detergent fiber than buffalo fed with LCM $(\mathrm{p}<0.05)$. Moreover, no interaction was

\begin{tabular}{|c|c|c|c|c|c|c|c|c|}
\hline & \multicolumn{2}{|c|}{$\mathrm{CC}^{1}$} & \multicolumn{2}{|c|}{ CR3:1 } & \multirow{2}{*}{ SEM } & \multicolumn{3}{|c|}{ Significance $^{2}$} \\
\hline & LCM & HCM & LCM & $\mathrm{HCM}$ & & $\mathrm{CS}$ & $\mathrm{CM}$ & $\mathrm{I}$ \\
\hline \multicolumn{9}{|l|}{ Total dry matter intake } \\
\hline $\mathrm{kg}$ & 6.4 & 6.1 & 6.5 & 6.2 & 0.18 & ns & 0.06 & ns \\
\hline $\mathrm{g} / \mathrm{kg} \mathrm{BW}$ & 24.1 & 22.4 & 25.3 & 22.4 & 0.12 & ns & $*$ & ns \\
\hline $\mathrm{g} / \mathrm{kg} \mathrm{BW} \mathrm{BW}^{0.75}$ & 90.1 & 87.0 & 90.7 & 91 & 1.22 & ns & ns & ns \\
\hline \multicolumn{9}{|c|}{ Urea-treated rice straw intake } \\
\hline $\mathrm{kg}$ & 5.0 & 4.7 & 5.2 & 4.8 & 0.14 & ns & $*$ & ns \\
\hline $\mathrm{g} / \mathrm{kg} \mathrm{BW}$ & 18.7 & 17.3 & 19.8 & 174 & 0.11 & ns & 0.06 & ns \\
\hline $\mathrm{g} / \mathrm{kg} \mathrm{BW} \mathrm{BW}^{0.75}$ & 73.5 & 69.7 & 73.9 & 70.3 & 1.02 & ns & $*$ & ns \\
\hline \multicolumn{9}{|l|}{ Nutrient intake (kg) } \\
\hline Organic matter & 6.1 & 5.9 & 6.2 & 6.0 & 0.16 & ns & $*$ & ns \\
\hline Crude protein & 0.5 & 0.5 & 0.5 & 0.5 & 0.01 & ns & ns & ns \\
\hline Neutral detergent fiber & 3.4 & 3.2 & 3.6 & 3.3 & 0.26 & ns & $*$ & ns \\
\hline Acid detergent fiber & 2.7 & 2.4 & 2.7 & 2.5 & 0.10 & ns & $*$ & ns \\
\hline
\end{tabular}
found between carbohydrate sources and levels of $\mathrm{CM}$ on

Table 3. Effect of carbohydrate sources and cottonseed meal levels on total dry matter, urea-treated rice straw and nutrient intakes

${ }^{1} \mathrm{CC}=$ Cassava chip, CR3:1 = Cassava chip+rice bran 3:1, LCM = Low cottonseed meal, HCM = High cottonseed meal.

${ }^{2} \mathrm{CS}=$ Energy sources, $\mathrm{CM}=$ Cotton seed meal levels, $\mathrm{I}=\mathrm{ES} \times \mathrm{CM}$ interaction.

$* \mathrm{p}<0.05, \mathrm{~ns}=$ Non-significantly different, SEM $=$ Standard error of the means. 
Table 4. Effect of carbohydrate sources and cottonseed meal levels on nutrient digested and nutrient digestibility

\begin{tabular}{|c|c|c|c|c|c|c|c|c|}
\hline & \multicolumn{2}{|c|}{$\mathrm{CC}^{1}$} & \multicolumn{2}{|c|}{ CR3:1 } & \multirow{2}{*}{ SEM } & \multicolumn{3}{|c|}{ Significance $^{2}$} \\
\hline & LCM & HCM & LCM & $\mathrm{HCM}$ & & $\mathrm{CS}$ & $\mathrm{CM}$ & I \\
\hline \multicolumn{9}{|c|}{ Nutrient digestibility (g/kg DM) } \\
\hline Dry matter & 673 & 634 & 602 & 652 & 30.2 & $\mathrm{~ns}$ & ns & $*$ \\
\hline Organic matter & 701 & 692 & 671 & 702 & 28.5 & ns & ns & ns \\
\hline Crude protein & 552 & 540 & 521 & 548 & 21.9 & ns & ns & ns \\
\hline Neutral detergent fiber & 631 & 600 & 560 & 614 & 32.1 & ns & ns & ns \\
\hline Acid detergent fiber & 563 & 562 & 552 & 601 & 23.4 & ns & ns & ns \\
\hline \multicolumn{9}{|l|}{ Nutrient digested $(\mathrm{kg})$} \\
\hline Dry matter & 3.9 & 3.7 & 3.9 & 3.5 & 0.18 & ns & $*$ & $\mathrm{~ns}$ \\
\hline Organic matter & 3.7 & 3.5 & 3.7 & 3.3 & 0.16 & $\mathrm{~ns}$ & $*$ & $\mathrm{~ns}$ \\
\hline Crude protein & 0.3 & 0.3 & 0.2 & 0.3 & 0.02 & ns & ns & ns \\
\hline Neutral detergent fiber & 2.2 & 2.0 & 2.1 & 1.9 & 0.11 & ns & $*$ & $\mathrm{~ns}$ \\
\hline Acid detergent fiber & 1.4 & 1.3 & 1.6 & 1.3 & 0.10 & $\mathrm{~ns}$ & * & $\mathrm{ns}$ \\
\hline
\end{tabular}

${ }^{1}$ CC = Cassava chip, CR3:1 = Cassava chip+rice bran 3:1, LCM = Low cottonseed meal, HCM = High cottonseed meal.

${ }^{2} \mathrm{CS}=$ Energy sources, $\mathrm{CM}=$ Cotton seed meal levels, $\mathrm{I}=\mathrm{ES} \times \mathrm{CM}$ interaction.

$* \mathrm{p}<0.05, \mathrm{~ns}=$ Non-significantly different, $\mathrm{SEM}=$ Standard error of the means.

voluntary feed intake of swamp buffaloes $(\mathrm{p}>0.05)$.

Table 4 shows the effect of carbohydrate source and cottonseed meal level on nutrient digestibility and nutrients digested in swamp buffaloes. Carbohydrate source and cottonseed meal level did not affect nutrient digestibility including DM, OM, CP, NDF and ADF of swamp buffalo ( $>0.05)$. Dry matter digestibility was affected by an interaction between carbohydrate source and cottonseed meal level $(\mathrm{p}<0.05)$ while digestibility of other nutrients was not significantly different among treatments $(p>005)$. The amount of nutrients digested was not affected by carbohydrate sources ( $p>0.05)$, while the amount of DM, $\mathrm{OM}, \mathrm{NDF}$ and ADF digested were lower in buffalo fed with HCM when compared to buffalo fed with LCM $(p<0.05)$.

From Table 5, ruminal $\mathrm{pH}$ at 0 and $2 \mathrm{~h}$-post feeding in the rumen of swamp buffaloes were similar among treatments ( $p>0.05)$. However, buffalo receiving CR3:1 as a carbohydrate source had a higher ruminal $\mathrm{pH}$ than the $\mathrm{CC}$ fed animals $(p<0.05)$ at $6 \mathrm{~h}$-post feeding while those receiving $\mathrm{LCM}$ had a higher ruminal $\mathrm{pH}$ than the $\mathrm{HCM}$ treatment at $4 \mathrm{~h}$-post feeding $(\mathrm{p}<0.05)$. Moreover, ruminal $\mathrm{pH}$ at 0 and 2 h-post feeding were affected by carbohydrate source and cottonseed meal level interaction $(\mathrm{p}<0.05)$. Carbohydrate sources did not affect ruminal ammonia concentration at any sampling time $(p>0.05)$. Ruminal ammonia nitrogen in the rumen at $4 \mathrm{~h}$-post feeding was lower in buffalo receiving HCM when compared with the LCM group $(\mathrm{p}<0.05)$.

The effect of dietary treatments on the microbial population was that the population of protozoa in the rumen of swamp buffalo was similar among groups before morning feeding $(p>0.05)$. However buffalo which received CR3:1 had lower numbers of protozoa than buffalo fed on the $\mathrm{CC}$ treatment $(\mathrm{p}<0.05)$. The number of fungal zoospores, measured by the direct count technique, was not affected by either carbohydrate source or cottonseed meal level

Table 5. Effect of carbohydrate sources and cottonseed meal levels on ruminal $\mathrm{pH}$ and ammonia nitrogen concentration

\begin{tabular}{|c|c|c|c|c|c|c|c|c|c|}
\hline & & \multicolumn{2}{|c|}{$\mathrm{CC}^{1}$} & \multicolumn{2}{|c|}{ CR3:1 } & \multirow{2}{*}{ SEM } & \multicolumn{3}{|c|}{ Significance $^{2}$} \\
\hline & & LCM & $\mathrm{HCM}$ & LCM & $\mathrm{HCM}$ & & $\mathrm{CS}$ & $\mathrm{CM}$ & $\mathrm{I}$ \\
\hline \multicolumn{10}{|l|}{ Ruminal $\mathrm{pH}$} \\
\hline \multirow[t]{4}{*}{ h-post feeding } & 0 & 6.7 & 6.6 & 6.6 & 6.7 & 0.05 & ns & ns & $*$ \\
\hline & 2 & 6.6 & 6.5 & 6.5 & 6.7 & 0.04 & ns & ns & $*$ \\
\hline & 4 & 6.6 & 6.3 & 6.5 & 6.4 & 0.07 & $\mathrm{~ns}$ & $*$ & ns \\
\hline & 6 & 6.3 & 6.3 & 6.4 & 6.4 & 0.04 & $*$ & ns & ns \\
\hline \multicolumn{10}{|c|}{ Ruminal $\mathrm{NH}_{3}-\mathrm{N}$ concentration $(\mathrm{mg} / \mathrm{dl})$} \\
\hline \multirow[t]{4}{*}{ h-post feeding } & 0 & 9.3 & 10.2 & 7.3 & 10.1 & 1.46 & $\mathrm{~ns}$ & $\mathrm{~ns}$ & ns \\
\hline & 2 & 16.0 & 20.5 & 22.1 & 20.1 & 4.21 & $\mathrm{~ns}$ & $\mathrm{~ns}$ & ns \\
\hline & 4 & 16.1 & 12.8 & 17.8 & 13.1 & 0.97 & $\mathrm{~ns}$ & $*$ & $\mathrm{~ns}$ \\
\hline & 6 & 11.0 & 12.8 & 11.5 & 13.1 & 2.06 & ns & ns & ns \\
\hline
\end{tabular}

${ }^{1} \mathrm{CC}=$ Cassava chip, CR3:1 = Cassava chip+rice bran 3:1, LCM = Low cottonseed meal, HCM = High cottonseed meal.

${ }^{2} \mathrm{CS}=$ Energy sources, $\mathrm{CM}=$ Cotton seed meal levels, $\mathrm{I}=\mathrm{ES} \times \mathrm{CM}$ interaction.

$* \mathrm{p}<0.05, \mathrm{~ns}=$ Non-significantly different, SEM $=$ Standard error of the means. 
Table 6. Effect of carbohydrate sources and cottonseed meal levels on microbial population in the rumen

\begin{tabular}{|c|c|c|c|c|c|c|c|c|c|}
\hline & & \multicolumn{2}{|c|}{$\mathrm{CC}^{1}$} & \multicolumn{2}{|c|}{ CR3:1 } & \multirow{2}{*}{ SEM } & \multicolumn{3}{|c|}{ Significance $^{2}$} \\
\hline & & LCM & HCM & LCM & HCM & & $\mathrm{CS}$ & $\mathrm{CM}$ & I \\
\hline \multicolumn{10}{|c|}{ Protozoa $\left(\times 10^{5}\right.$ cell $\left./ \mathrm{ml}\right)$} \\
\hline \multirow[t]{2}{*}{ h-post feeding } & 0 & 6.4 & 6.8 & 5.9 & 6.3 & 1.23 & ns & ns & ns \\
\hline & 4 & 7.2 & 6.8 & 6.4 & 6.2 & 1.51 & $*$ & ns & ns \\
\hline \multicolumn{10}{|c|}{ Zoospores $\left(\times 10^{6} \mathrm{cell} / \mathrm{ml}\right)$} \\
\hline \multirow[t]{2}{*}{ h-post feeding } & 0 & 2.4 & 1.8 & 1.9 & 2.2 & 1.62 & ns & ns & ns \\
\hline & 4 & 2.0 & 2.1 & 1.7 & 2.1 & 1.48 & ns & ns & ns \\
\hline \multicolumn{10}{|c|}{ Total viable bacteria $\left(\times 10^{10} \mathrm{CFU}^{3} / \mathrm{ml}\right)$} \\
\hline \multirow[t]{2}{*}{ h-post feeding } & 0 & 9.3 & 8.6 & 9.4 & 8.5 & 1.57 & ns & $*$ & ns \\
\hline & 4 & 9.5 & 9.0 & 9.4 & 8.8 & 1.62 & ns & $*$ & ns \\
\hline \multicolumn{10}{|c|}{ Cellulolytic bacteria $\left(\times 10^{10} \mathrm{CFU} / \mathrm{ml}\right)$} \\
\hline \multirow[t]{2}{*}{ h-post feeding } & 0 & 7.0 & 6.3 & 6.5 & 7.5 & 1.62 & ns & $*$ & ns \\
\hline & 4 & 7.4 & 6.8 & 7.4 & 7.0 & 1.95 & ns & $*$ & ns \\
\hline \multicolumn{10}{|c|}{ Amylolytic bacteria $\left(\times 10^{8} \mathrm{CFU} / \mathrm{ml}\right)$} \\
\hline \multirow[t]{2}{*}{ h-post feeding } & 0 & 3.7 & 4.1 & 3.6 & 3.6 & 1.22 & ns & ns & ns \\
\hline & 4 & 4.2 & 4.3 & 3.8 & 3.9 & 1.37 & 0.08 & ns & ns \\
\hline \multicolumn{10}{|c|}{ Proteolytic bacteria $\left(\times 10^{8} \mathrm{CFU} / \mathrm{ml}\right)$} \\
\hline \multirow[t]{2}{*}{ h-post feeding } & 0 & 2.5 & 2.4 & 2.7 & 2.5 & 1.56 & ns & ns & ns \\
\hline & 4 & 2.7 & 2.6 & 2.6 & 2.5 & 2.01 & ns & ns & ns \\
\hline
\end{tabular}

${ }^{1} \mathrm{CC}=$ Cassava chip, CR3:1 = Cassava chip+rice bran 3:1, LCM = Low cottonseed meal, HCM = High cottonseed meal.

${ }^{2} \mathrm{CS}=$ Energy sources, $\mathrm{CM}=$ Cotton seed meal levels, $\mathrm{I}=\mathrm{ES} \times \mathrm{CM}$ interaction.

${ }^{3} \mathrm{CFU}=$ Colony forming unit. $* \mathrm{p}<0.05, \mathrm{~ns}=$ Non-significantly different, $\mathrm{SEM}=$ Standard error of the means.

$(\mathrm{p}<0.05)$. Carbohydrate source did not affect viable bacteria numbers as measured by the roll tube technique (Total viable, cellulolytic, proteolytic, amylolytic bacteria; $\mathrm{p}>0.07$ ), although at $4 \mathrm{~h}$-post feeding the population of amylolytic bacteria tended to be higher in the $\mathrm{CC}$ group than in the CR3:1 group $(p<0.08)$. The populations of total viable and cellulolytic bacteria were lower in buffalo fed with HCM $(p<0.05)$ while amylolytic and proteolytic bacteria were not significantly different $(p>0.05)$ to buffalo fed with LCM (Table 6).

Table 7 shows that carbohydrate source did not affect microbial protein synthesis in terms of microbial $\mathrm{N}$ supply, microbial protein yield or efficiency of synthesis. Microbial $\mathrm{N}$ supply and microbial protein yield were lower in buffalo fed with HCM when compared with LCM $(p<0.05)$. However, CM level did not affect microbial protein synthesis efficiency of swamp buffalo ( $p>0.05$ ).

\section{DISCUSSION}

Carbohydrate source did not affect feed intake or nutrient digestibility. This could imply that both cassava chip and cassava chip combined with rice bran can be used as a carbohydrate (energy) sources in concentrates for swamp buffalo. However, the use of easily rumen degradable carbohydrate feedstuff might be expected to impact on feed intake due to its high rate of volatile fatty acid production and reduction of ruminal $\mathrm{pH}$ (Sommart et al., 1997; Richardson et al, 2003; Wang et al., 2009) and the decreased microbial fermentation in the rumen (Firkins, 1996; Russell and Rychlik, 2001; Firkins et al., 2006). The different results from the present study may be due to

Table 7. Effect of carbohydrate sources and cottonseed meal levels on microbial protein synthesis

\begin{tabular}{|c|c|c|c|c|c|c|c|c|}
\hline & \multicolumn{2}{|c|}{$\mathrm{CC}^{1}$} & \multicolumn{2}{|c|}{ CR3:1 } & \multirow{2}{*}{ SEM } & \multicolumn{3}{|c|}{ Significance $^{2}$} \\
\hline & LCM & $\mathrm{HCM}$ & LCM & $\mathrm{HCM}$ & & $\mathrm{CS}$ & $\mathrm{CM}$ & I \\
\hline \multicolumn{9}{|l|}{ Microbial protein synthesis } \\
\hline Microbial N supply (g N/d) & 79.4 & 70.6 & 80.6 & 68.8 & 4.27 & ns & $*$ & ns \\
\hline Microbial protein production $(\mathrm{g} / \mathrm{d})$ & 453.8 & 441.3 & 455.0 & 435.0 & 3.62 & ns & $*$ & ns \\
\hline $\begin{array}{l}\text { Efficiency of microbial protein } \\
\text { synthesis } \mathrm{g} \mathrm{N} / \mathrm{kg} \mathrm{OMDR}^{3}\end{array}$ & 31.62 & 32.75 & 32.27 & 31.94 & 1.83 & ns & ns & ns \\
\hline
\end{tabular}

${ }^{1} \mathrm{CC}=$ Cassava chip, CR3:1 = Cassava chip+rice bran 3:1, LCM = Low cottonseed meal, HCM = High cottonseed meal.

${ }^{2} \mathrm{CS}=$ Energy sources, $\mathrm{CM}=$ Cotton seed meal levels, $\mathrm{I}=\mathrm{ES} \times \mathrm{CM}$ interaction.

$* \mathrm{p}<0.05, \mathrm{~ns}=$ Non-significantly different, SEM $=$ Standard error of the means.

${ }^{3}$ OMDR = Organic matter digestible in the rumen $(650 \mathrm{~g} / \mathrm{kg}$ DM of organic matter digestible in total tract) according to ARC (1984). 
microbes in the rumen of swamp buffalo were able to adapt themselves to changing substrates (Wanapat et al., 2009). Buffalo fed with HCM had a lower intake of urea-treated rice straw and digested nutrients than those fed with LCM. However, nutrient digestibilities were similar between the two levels of cottonseed meal which could be explained that buffaloes have greater capability to digest mixed substrates, particularly those with low nutritional values (Devendra, 1985; Wanapat and Wachirapakorn, 1990).

Ruminal $\mathrm{pH}$ was within the optimum range (6.3 to 6.7) and was found to be similar to other studies (Chanjula et al., 2004; Granum et al., 2007; Wanapat et al., 2009). The differences in ruminal $\mathrm{pH}$ between buffalo receiving $\mathrm{CC}$ and CR3:1 could be due to the rate of degradation of cassava chip which is higher than rice bran (Chanjula et al., 2003). Digestion of carbohydrate by rumen microbes will produce volatile fatty acids which will influence changes of ruminal pH (Wang et al., 2009). Buffalo which received LCM had higher ruminal $\mathrm{pH}$ than the HCM treatment and this could have resulted from the lower ruminal ammonia nitrogen concentration in the HCM than LCM treatments because ammonia nitrogen has property by a base, so this could be one reason why ruminal $\mathrm{pH}$ was different among the groups. The concentration of ammonia in the rumen depends on protein degradation which in turn is dependent upon many factors such as the solubility of the protein, the amount of protein in the ration and probably the level of dry matter intake (Church, 1969). In addition, it may be due to differences in ammonia assimilation by bacteria in the rumen (Erfle et al., 1977). Ruminal pH was affected more quickly by carbohydrate source and cottonseed meal levels after morning feeding ( 0 and $2 \mathrm{~h}$-post feeding). This result indicated that diet feed could improve rumen fermentation by providing suitable $\mathrm{pH}$ conditions (6.3 to 7.0) for microorganism activity as reported by Hungate (1966).

Buffalo which received CC had higher numbers of protozoa than buffalo fed on CR3:1. This result is in agreement with Mendoza et al. (1993) and Wanapat et al. (2009) who reported that the number of protozoa decreased when the proportion of starch in the diets decreased as the main source of energy for protozoa particularly Entodiniomoph spp. is starch (Hungate, 1966). However, some reports indicated that grain fed feedlot cattle are virtually free (Eadie et al., 1970; Lyle et al., 1981) or have dramatically reduced populations (Slyter et al., 1970; Vance et al., 1972) of protozoa because of the acidic conditions in the rumen. The population of amylolytic bacteria in the rumen could be increased when ruminants receive a higher proportion of easily rumen degradable carbohydrate (Hungate, 1966; Tajima et al., 2001). However, the population of amylolytic bacteria in the present study only showed a trend towards being higher in the CC than the CR3:1 treatment. This may be due to the capacity of protozoa to store starch granules (Abou Akkada and Howard, 1960), which then reduces the availability of starch for microbial growth (Eadie and Mann, 1970). Fungi may form a significant part of the rumen contents in ruminants fed on fibrous diets and play an important role in fiber digestion (Bauchop, 1979). However, the number of fungal zoospores in this study was not affected by either carbohydrate source or cottonseed meal level. This might be influenced by other factors particularly residence time of feed particles in the rumen (Joblin, 1981), as populations will be rapidly depleted if they are unable to attach to feed particles and passage from the rumen is delayed. Populations of total viable and cellulolytic bacteria were lower in buffalo fed with HCM than with LCM. These results could be a response to roughage intake and fiber intake of buffalo which were higher in the LCM fed animals. This finding is in agreement with Dehority and Tirabasso (1998) who reported that the population of cellulolytic bacteria in the rumen was increased by feeding a diet that contained 550 to $650 \mathrm{~g} / \mathrm{kg}$ DM purified cellulose although the population of cellulolytic bacteria is not the limiting factor in the digestion of cellulose in the rumen. Proteolytic bacteria numbers were similar between the two levels of cottonseed meal diets while Bach et al. (2005) reported that proteolytic bacteria numbers were reduced when a high proportion of rumen undegradable protein was offered. The different rumen ecology of swamp buffalo from other ruminants could contribute to their different response to different feeds (Wanapat et al., 2003).

Microbial N supply and microbial protein yield were similar between the two carbohydrate sources while they were lower in buffalo fed with HCM than LCM. These results could be due to the feed intake and rumen fermentation responses. Microbial protein leaving the rumen ultimately provides a source of amino acids for the host animal as the protein is digested and absorbed in the small intestine (Church, 1969; Clark et al., 1992). However, there are many factors that affect the amount of microbial protein synthesis such as rate of ruminal degradability of nitrogen and carbohydrate sources, rumen dilution rate, dietary sulfur and frequency of feeding, etc. (Stern and Hoover, 1979). Cottonseed meal level did not affect microbial protein synthesis efficiency of swamp buffalo. As the result shown that proteolytic bacteria and $\mathrm{NH}_{3}-\mathrm{N}$ concentration not difference by cottonseed meal. This may imply that buffalo which received the LCM diet should obtain more protein from microbial cells than HCM group, but buffalo which received the HCM diet may obtain amino acids from cottonseed meal available in the small intestine directly as this diet contains a high proportion of by-pass protein (Clark et al., 1987). The ability to use cottonseed meal with different sources of energy in a concentrate mixture would be a useful and efficient strategy for farmers 
who need to find an alternative means to reduce feed costs and a simple way of feeding based on locally available feed resources especially in the developing countries.

Based on the results, it appears swamp buffaloes were able to utilize a higher proportion of rumen fermentable carbohydrate in the diet than young dairy bulls (Wananat et al., 2013) or beef cattle (Wanapat et al., 2012). This could be due to the differences in rumen ecology, especially microbial population, as reported by Wanapat et al. (2003) who found that the ruminal protozoal population was lower, while bacteria and fungal zoospores populations were higher in the rumen of swamp buffalo as compared to cattle. In contrast, use of a high level of rumen by-pass protein dramatically reduced feed intake, nutrient digestibility, bacterial population and microbial protein synthesis of swamp buffalo. It indicated that nitrogen available in the rumen is very important for rumen microbes as Bryant and Robinson (1961) reported that cellulolytic bacteria used $\mathrm{NH}_{3}-\mathrm{N}$ as a major nitrogen source for their cell protein synthesis. Although by-pass protein is advantageous for the host ruminant to receive good quality protein directly from the diet, nitrogen available for rumen microbes for their growth and cell activities is equally vital and unavoidable (NRC, 2001)

Carbohydrate source did not affect feed intake, nutrient digestibility, rumen fermentation or microbial protein synthesis of swamp buffaloes. Buffalo fed with HCM had a lower roughage intake, population of bacteria and microbial nitrogen synthesis when compared with buffalo fed LCM. Therefore, LCM could be fed with cassava chip as an carbohydrate source in swamp buffaloes.

\section{REFERENCES}

Abou Akkada, A. R., and B. H. Howard. 1960. The biochemistry of rumen protozoa. 3-The carbohydrate metabolism of Entodinium. Biochem. J. 76:445-449.

AOAC. 1991. Official methods of analysis. Association of Official Analysis Chemists, DC. p. 1230.

AOAC. 1995. Official method of analysis, 16th ed. Animal Feeds: Association of Official Analytical Chemists, Virginia. pp. 1-18.

Agricultural Research Council. 1984. The nutrient requirements of ruminant livestock. Supplement No. 1., Commonwealth Agricultural Bureaux, Farnham Royal, UK. pp. 38-39.

Bach, A., S. Calsamiglia, and M. D. Stern. 2005. Nitrogen metabolism in the rumen. J. Dairy Sci. 88:E9-E21.

Bauchop, T. 1979. Rumen anaerobic fungi of cattle and sheep. Appl. Environ. Microbiol. 38:148-158.

Bremmer, J. M., and D. R. Keeney. 1965. Steam distillation methods to determination of ammonium, nitrate and nitrite. Anal. Chem. Acta. 32:485-495.

Bryant, M. P., and I. M. Robinson. 1961. Studies on the nitrogen requirements of some ruminal cellulolytic bacteria. Appl. Microbiol. 9:96-103.

Chanjula, P., M. Wanapat, C. Wachirapakorn, and P. Rowlinson.
2004. Effect of synchronizing starch sources and protein (NPN) in the rumen on feed intake, rumen microbial fermentation, nutrient utilization and performance of lactating dairy cows. Asian-Aust. J. Anim. Sci. 17:1400-1410.

Chanjula, P., M. Wanapat, C. Wachirapakorn, S. Uriyapongson, and P. Rowlinson. 2003. Ruminal degradability of tropical feeds and their potential use in ruminant diets. Asian-Aust. J. Anim. Sci. 16:211-216.

Chantaprasarn, N., and M. Wanapat. 2008. Effects of sunflower oil supplementation in cassava hay based-diets for lactating dairy cows. Asian-Aust. J. Anim. Sci. 21:42-50.

Chen, X. B., and M. J. Gomes. 1995. Estimation of microbial protein supply to sheep and cattle based on urinary excretion of purine perivatives -an overview of the technical details. Occasional Publication 1992. International Feed Resources Unit, Rowel Research Institude, Aberdeen.

Chen, X. B., D. J. Kyle, and E. R. Orskov. 1993. Measurement of allantoin in urine and plasma by high-performance liquid chromatography with pre-column derivatization. J. Chromathogr. B. Biomed. Sci. Appl. 617:241-247.

Cherdthong, A., M. Wanapat, P. Kongmun, R. Pilajun, and P. Khejornsart. 2010. Rumen fermentation, microbial protein synthesis and cellulolytic bacterial population of swamp buffaloes as affected by roughage to concentrate ratio. J. Anim. Vet. Adv. 9:1667-1675.

Church, D. C. 1969. Digestive Physiology and Nutrition of Ruminants. Volume I. Oregon State University. Corvallis. 316 p.

Clark, J. H., T. H. Klusmeyer, and M. R. Cameron. 1992. Microbial protein synthesis and flows of nitrogen fractions to the duodenum of dairy cows. J. Dairy Sci. 75:2304-2323.

Clark, J. H., M. R. Murphy, and B. A. Crooker. 1987. Supplying the protein needs of dairy cattle from by-product feeds. J. Dairy Sci. 70:1092-1109.

Dehority, B. A., and P. A. Tirabasso. 1998. Effect of ruminal cellulolytic bacterial concentrations on in situ digestion of forage cellulose. J. Anim. Sci. 76:2905-2911.

Devendra, C. 1985. Comparative nitrogen utilization in Malaysia Swamp buffaloes and Kedah-Kelanton cattle. In Proc. The $7^{\text {th }}$ AFAR Int. Workshop. (Ed. R. Diox), IDPD, Canberra, Australia.

Eadie, J. M., J. S. Hyldgaard-Jensen, O. R. Mann, S. Reid, and P. G. Whitelaw. 1970. Observations on the microbiology and biochemistry of the rumen in cattle given different quantities of a pelleted barley ration. Br. J. Nutr. 24:157-163.

Eadie, J. M., and S. O. Mann. 1970. Development of the rumen microbial population: High starch diets and instability. In: Physiology of Digestion and Metabolism in the Ruminant (Ed. A. T. Philipson). Oriel Press, Newcastle Upon Tyne. pp. 335347.

Erfle, J. D., F. D. Sauer, and S. Mahadevan. 1977. Effect of ammonia concentration on activity of enzymes of ammonia assimilation and on synthesis of amino acids by mixed rumen bacteria in continuous culture. J. Dairy Sci. 60:1064-1072.

Etman, K. E. I., I. M. Soliman, I. A. S. Abou-Selim, and A. A. Soliman. 1993. Cassava (Manihot esculenta, crantz.) in rations of buffaloes: E. Effect of partial replacement of yellow corn by cassava pellets in rations of growing buffaloes calves. In: Prospects of buffalo production in the Mediterranean and the 
Middle East, (Ed. M. Shafie, A. H. Barkawi, S. A. Ibrahim and R. R. Sadek). Cairo, Egypt. Pudoc Scientific Publishers, Wageningen. pp. 302-304.

Galyean, M. 1989. Laboratory procedure in animal nutrition research. Department of Animal and Life Science. New Mexico State University. p. 193.

Granum, G., M. Wanapat, P. Pakdee, C. Wachirapakorn, and W. Toburan. 2007. A comparative study on the effect of cassava hay supplementation in swamp buffaloes (Bubalus bubalis) and cattle (Bos indicus). Asian-Aust. J. Anim. Sci. 20:13891396.

Grings, E. E., R. E. Roffler, and D. P. Deitelhoff. 1991. Response of dairy cows in early lactation to additions of cottonseed meal in alfalfa-based diets. J. Dairy Sci. 74:2580-2587.

Firkins, J. L. 1996. Maximizing microbial protein synthesis in the rumen. J. Nurtr. 126:1347s-1354s.

Firkins, J. L., A. N. Hristov, M. B. Hall, G. A. Varga, and N. R. StPierre. 2006. Integration of ruminal metabolism in dairy cattle. J. Dairy Sci. 89:E31-E51.

Hungate, R. E. 1966. The rumen and its microbes. Academic Press. New York and London. p. 533.

Hungate, R. E. 1969. A roll tube method for cultivation of strict anaerobes. In: Methods in Microbiology, edited by Norris (Ed. J. R. Norris and D. W. Ribbons), New York. Academic. NY. pp. 313.

Joblin, K. N. 1981. Isolation, enumeration and maintenance of rumen anaerobic fungi in roll tubes. Appl. Environ. Microbiol. 42:1119-1122.

Khampa, S., M. Wanapat, C. Wachirapakorn, N. Nontaso, and M. Wattiaux. 2006. Effects of urea level and sodium DL-malate in concentrate containing high cassava chip on ruminal fermentation efficiency, microbial protein synthesis in lactating dairy cows raised under tropical condition. Asian-Aust. J. Anim. Sci. 19:837-841.

Lyle, R. R., R. R. Johnson, J. V. Wilhite, and W. R. Backus. 1981. Ruminal characteristics insteersas affected by adaptation from forage to all-concentrate diets. J. Anim. Sci. 53:1383-1388.

Mendoza, G. D., R. A. Britton, and R. A. Stock. 1993. Influence of ruminal protozoa on site and extent of starch digestion and ruminal fermentation. J. Anim. Sci. 71:1572-1578.

National Research Council. 2001. Nutrient requirements of dairy cattle, 7th rev. ed. Washington, D.C.: National Academy Press. p. 408.

Promkot, C., M. Wanapat, C. Wachirapakorn, and C. Navanukraw. 2007. Influence of sulfur on fresh cassava foliage and cassava hay incubated in rumen fluid of beef cattle. Asian-Aust. J. Anim. Sci. 20:1424-1432.

Richardson, J. M., R. G. Wilkinson, and L. A. Sinclair. 2003. Synchrony of nutrient supply to the rumen and dietary energy source and their effects on the growth and metabolism of lambs. J. Anim. Sci. 81:1332-1347.

Russell, J. B., and J. L. Rychlik. 2001. Factors that alter rumen microbial ecology. Science 292:1119-1122.

Samuel, M., S. Sagathewan, J. Thomas, and G. Mathen. 1997. An HPLC method for estimation of volatile fatty acids of ruminal fluid. Indian J. Anim. Sci. 67:805-807.

SAS. User's Guide: Statistic, Version 5. Edition. 1996. SAS. Inst Cary, N.C.

Sommart, K., M. Wanapat, P. Rowlinson, and D. S. Parker. 1997.
The effects of nonstructural carbohydrate and dietary protein on feed intake, ruminal fermentation and cow performance. In: Proceedings of the British Society of Animal Science, March 1997. British Society of Animal, Scarborough. pp. 97-98.

Stern, M. D., and W. H. Hoover. 1979. Methods for determining and factors affecting rumen microbial protein synthesis: a review. J. Anim. Sci. 49:1590-1603.

Slyter, L. L., R. R. Oltjen, D. L. Kern, and F. C. Blank, 1970. Influence of type and level of grain and diethylstilbestrol on the rumen microbial populations of steers fed all-concentrate diets. J. Anim. Sci. 31:996-1002.

Tajima, M., R. I. Aminov, T. H. Nagamine, M. M. Nakamura, and Y. Benno. 2001. Diet-dependent shifts in the bacterial population of the rumen revealed with real-time PCR. Appl. Environ. Microbiol. 67:2766-2774.

Vance, R. D., R. L. Preston, E. W. Klosterman, and V. R. Cahill. 1972. Utilization of whole shelled and crimped corn grain with varying proportions of corn silage by growing-finishing steers. J. Anim. Sci. 35:598-605.

Van Soest, P. J., J. B. Robertson, and B. A. Lewis. 1991. Methods of dietary fiber, neutral detergent fiber and non-starch carbohydrates in relation to animal nutrition. J. Dairy Sci. 74: 3583-3597.

Wanapat, M. 2003. Manipulation of cassava cultivation and utilization to improve protein to energy biomass for livestock feeding in the tropics. Asian-Aust. J. Anim. Sci. 16:463-472.

Wanapat, M. 2009. Potential uses of local feed resources for ruminants. Trop. Anim. Health Prod. 41:1035-1049.

Wanapat, M., and S. Khampa. 2007. Effect of levels of supplementation of concentrate containing high levels of cassava chip on rumen ecology, microbial $\mathrm{N}$ supply and digestibility of nutrients in beef cattle. Asian-Aust. J. Anim. Sci. 20:75-81.

Wanapat, M., N. Nontaso, C. Yuangklang, S. Wora-anu, A. Ngarmsang, C. Wachirapakorn, and P. Rowlinson. 2003. Comparative study between swamp buffalo and native cattle in feed digestibility and potential transfer of buffalo rumen digesta into cattle. Asian-Aust. J. Anim. Sci. 16:504-510.

Wanapat, M., R. Pilajun, and P. Kongmun. 2009. Ruminal ecology of swamp buffalo as influenced by dietary sources. Anim. Feed Sci. Technol. 151:205-214.

Wanapat, M., S. Foiklang, P. Rowlinson, and R. Pilajun. 2012. Effect of carbohydrate sources and cotton seed meal in the concentrate: II. Feed intake, nutrient digestibility, rumen fermentation and microbial protein synthesis in beef cattle. Trop. Anim. Health Prod. 44:35-42.

Wanapat, M., N. Anantasook, P. Rowlinson, R. Pilajun, and P. Gunun. 2013. Effect of carbohydrate sources and levels of cotton seed meal in concentrate on feed intake, nutrient digestibility, rumen fermentation and microbial protein synthesis in young dairy bulls. Asian-Aust. J. Anim. Sci. 26: 529-536.

Wanapat, M., R. Pilajun, and P. Rowlinson. 2012. Effect of carbohydrate source and cottonseed meal level in the concentrate: IV. Feed intake, rumen fermentation and milk production in milking cows. Trop. Anim. Health Prod. DOI 10.1007/s11250-012-0238-6.

Wanapat, M., and P. Rowlinson. 2007. Nutrition and feeding of swamp buffalo: feed resources and rumen approach. Italian J. 
Anim. Sci. 6 (Suppl. 1): 67-73.

Wanapat, M., and C. Wachirapakorn. 1990. Utilization of roughage and concentrate by feedlot swamp buffaloes Bubalus bubalis. Asian-Aus. J. Anim. Sci. 3:195-203.

Wang, Y. H., M. Xua, F. N. Wang, Z. P. Yu, J. H. Yao, L. S. Zan, and F. X. Yang. 2009. Effect of dietary starch on rumen and small intestine morphology and digesta $\mathrm{pH}$ in goats. Livest. Sci. 122:48-52.
Wora-anu, S. 2006. Study on predominant ruminal cellulolytic bacteria in ruminants under various rumen ecology. Ph.D. Thesis. Khon Kaen University, Khon Kean.

Wora-Anu, S., M. Wanapat, C. Wachirapakorn, and N. Nontaso. 2007. Effect of roughage sources on cellulolytic bacteria and rumen ecology of beef cattle. Asian-Aust. J. Anim. Sci. 20:1705-1712. 